\author{
Галина Лялюк, \\ кандидат психологічних наук, доцент, \\ доцент кафедри психології діяльності \\ в особливих умовах, \\ Львівський державний університет внутрішніх справ \\ (Дрогобич, Україна) \\ Halyna Lialiuk, \\ PhD (Psychology), Assoc. Prof, \\ Assistant Professor at Department of Psychology \\ of Activities in Special Conditions, \\ Lviv State University of Internal Affairs \\ (Drohobych, Ukraine) \\ gala_psycholog@ukr.net \\ ORCID ID 0000-0002-4819-6247
}

Удк 37.015.311-058.862

\title{
ВЗАЄМНА ДОВІРА ЯК УМОВА ВИХОВАННЯ ДІТЕЙ-СИРІТ У КОНТЕКСТІ ОСОБИСТІСНОЇ ПАРАДИГМИ
}

\begin{abstract}
Анотація. У статті актуалізовано проблему впровадження інноваційних підходів у вихованні дітей-сиріт в Україні, що перебувають в державних закладах опіки. Метою статті є аналіз особливостей формування суб'єкт-суб'єктної взаємодії вихователя та дитини-сироти на основі принципу довіри.

Розглянуто основні положення особистісно-гуманістичної стратегії педагогічної парадигми, роль довірливих стосунків у суб'єкт-суб'єктній взаємодії педагога та вихованця. Зазначено, що виховання дітей-сиріт у контексті особистісної парадигми передбачає реалізацію принципу гуманізації виховання - сприйняття дитини як вищої соціальної цінності, визнання її прав на свободу, розвиток здібностей, виявлення її індивідуальності.

Здійснено аналіз феномену довіри на основі психолого-педагогічних наукових досліджень. Обґрунтовано необхідність реалізації принципу довіри опікунсько-виховної діяльності, який виступає умовою результативності продуктивного розвитку особистості дитини-сироти, уможливлює творче розкриття її унікальних потреб і здібностей, активізацію її особистісного ресурсу.

У суб'єкт-суб'єктній взаємодії вихователя та дитини-сироти довіра стимулює процес відвертості, «прозорості», саморозкриття, що виступає умовою результативності продуктивного розвитку особистості дитини-сироти. Тільки системна реалізація умов, дотримання яких забезпечить реалізацію принципу довіри у вихованні особистості дитини-сироти допоможе здійснити ефективну підтримку дітям, що залишились без піклування батьків, та підвищити успішність виховного процесу загалом.
\end{abstract}

Ключові слова: державні заклади опіки, діти-сироти, довіра, виховання, гуманізм, опіка, техніки досягнення довіри.

\section{THE MUTUAL TRUST AS A CONDITION FOR THE UPBRINGING ORPHAN CHILDREN IN THE CONTEXT OF THE PERSONALITY PARADIGM}

\footnotetext{
Abstract. The article deals with the problem of introducing innovative methods of upbringing orphans in Ukraine, that are staying in state care institutions.

The purpose of the article is to analyze the peculiarities of the formation of subject-subject interaction between the educator and the orphan on the basis of the principle of trust.

The main principles of the personal-humanistic strategy of the pedagogical paradigm, the role of trusting relations in the subject-subject interaction between the teacher and the pupil are considered. It is noted that the upbringing of orphans in the context of personal paradigm involves the implementation of the principle of humanization of education - the perception of the child as the highest social value, the recognition of his rights to freedom, development of abilities, identification of his individuality. The analysis of the phenomenon of trust is based on psychological and pedagogical researches. The necessity of realizing the principle of trust of guardianship and educational activity as a condition for the productive development of the orphan child's personality allowing creative disclosure of the child's unique needs and abilities is substantiated. In the subject-subject interaction between the educator and the orphan, trust stimulates the process of openness, "transparency", self-disclosure, which is a condition for the effectiveness of the productive development of the orphan's personality.

The emotional subject-subject interaction between the orphan and the teacher, which is based on their mutual trust, is one of the pedagogical conditions for the successful upbringing of orphans.

The professional competence of teachers, the educator's use of techniques to achieve trust in the relationship with the child, will partially reduce the negative impact of the deprivation conditions of the state guardianship institution. Only the
} 
systematic implementation of conditions will ensure carrying out the principle of trust in the upbringing of the orphan, will help to provide the effective support to the children who are left without parental care and will increase the success of the educational process in general.

Keywords: state guardianship institutions, orphans, trust, upbringing, humanism, guardianship, trust-building techniques.

\section{ВСТУП}

Постановка проблеми. Проблема сирітства для українського суспільства має сьогодні державне значення та потребує від педагогічної науки нової філософії, нестандартних підходів до опіки та виховання дітейсиріт. Визнання Україною сім'ї як пріоритетної форми влаштування дітей-сиріт, на жаль, тільки фрагментарно розв'язало проблеми сирітства, через нерозвиненість сімейних форм опіки в нашій країні значна кількість дітей цієї категорії продовжує виховуватися в інтернатних закладах освіти. У сучасних українських реаліях формується нове бачення організації виховання, опіки, соціального захисту дітей, які потребують державної допомоги й підтримки. Необхідною постає проблема впровадження інноваційних підходів задля надання професійної допомоги дітям-сиротам на основі науково обґрунтованих концепцій виховання.

у суспільстві останнім часом простежується зниження рівня довіри на тлі демагогічної політики демонстрування «благодійності» у соціальних інституціях. Особливо гостро стоїть проблема формування базової довіри в дітей-сиріт, які виховуються в державник закладах опіки.

Аналіз наукових досліджень і публікацій. Окремі аспекти опіки та виховання дітей-сиріт вивчали в історикопедагогічних (Р.Волянюк, З.Нагачевська, О.Карпенко, Л. Фуштей), психолого-педагогічних (Л.Волинець, А.Капська, Н.Лисенко, І.Пєша, А. Поляничко, Н. Султанова, Б.Ступарик) вимірах. Психолого-педагогічні особливості вихованців державних закладів висвітлено в наукових розвідках Г. Бевз, О. Безпалько, Л. Волинець, Я. Гошовського, А. Прихожан, Н. Толстих та ін. Найбільш вагомими проблемами виховання дітей-сиріт в умовах дитячих будинків та інтернатів залишаються: вимушені умови спільного проживання дітей, що породжують обмеженість стосунків, напруження, тривожність, конкуренцію, агресію й інші негативні прояви психічного розвитку дітей; сегрегація вихованців в умовах утримання й «відчуження» дітей-сиріт від реальних життєвих проблем, позаяк певна «закритість» державних закладів опіки зумовлює обмеженість їхньої життєдіяльності в предметному й соціальному середовищі» (Султанова Н., 2018, с. 28). Істотним і особливо складним аспектом проблеми виховання дітей-сиріт залишається їх особистісний розвиток. Емоційний контакт дитини й вихователя, який будується на їхній взаємній довірі, є однією з педагогічних умов соціального виховання дітей у дитячих будинках та закладах інтернатного типу (Пеша І., 2000).

Визначення теоретичних основ розробки сучасних моделей виховання особистості дитини-сироти в умовах диверсифікації освітньо-виховного простору в Україні передбачає звернення до теоретико-методологічних засад педагогічної науки, зокрема парадигми виховання, яка виступає домінантою модернізації педагогічного процесу.

Особистісна парадигма виховання стала сьогодні однією із домінуючих в системі методолого-теоретичних норм і стандартів та аксіологічних критеріїв, що розкривають характерологічну цілісність освітньо-виховного процесу та регулюють науково-дослідницьку та практичну інноваційну педагогічну діяльність.

Виховання дітей-сиріт у контексті особистісної парадигми виховання не просто декларує, а утверджує дитину як найвищу цінність життя, передбачає визнання їі індивідуальності, самобутності, самоцінності. В центрі уваги дитина з її потребами, запитами, можливостями та здібностями, повага до особистості дитини, розуміння її запитів, інтересів, гідності, довіри до неї, виховання гуманної особистості, щирої, людяної, доброзичливої, милосердної. Формування суб'єкт-суб'єктних стосунків педагога й дитини-сироти є першоосновою й головною умовою виховання особистості; вони розвивають перцептивне, емоційне і когнітивне відображення педагогом та дитиною один одного (Бойко А. , 2012, с. 17). Однак у педагогічному процесі державних закладів опіки часто педагоги недооцінюють потужний виховний вплив «довіри», відтак простежуються труднощі у формуванні довірливих стосунків вихователя та дитИнИ-Сироти.

МЕТА I ЗАВДАНня ДОслІДЖЕНня - аналіз особливостей формування суб'єкт-суб'єктної взаємодії вихователя та дитини-сироти на основі принципу довіри.

\section{МЕТОДИ ДОСЛІДЖЕННЯ}

Для досягнення мети використано методи аналізу й синтезу, абстрагування, формалізації основних положень особистісної парадигми виховання, ідей упровадження інновацій у виховний процес державних закладів опіки.

\section{РЕЗУЛЬТАТИ ДОСЛІДЖЕННЯ}

Гуманізація виховання дітей-сиріт у контексті особистісної парадигми передбачає повагу до особистості дитини, педагогічну підтримку, зосередженість на її потребах, розуміння її запитів, інтересів, гідності, довіри до неї, виховання гуманної особистості, щирої, людяної, доброзичливої, милосердної (Я. Корчак, А. Макаренко, В. Сухомлинський, К. Ушинський).

Феномен довіри - багатоаспектне явище, яке відіграє одну з основних ролей у міжособистісній взаємодії та $€$ головною умовою формування позитивних міжособистісних відносин. Саме довіра дає змогу визначити ступінь близькості між людьми, на її основі будуються найміцніші стосунки. Міра довіри як до соціуму, так і до себе є одним з глибинних чинників, що впливають на успішність та прагнення до особистісного росту і розвитку. Довіра передбачає віру в Іншого. Здатність вірити в Іншого ґрунтована на вірі в себе, довірі до себе. У інтерсуб'єктних комунікаціях довіра стимулює процес відвертості, «прозорості», саморозкриття, що є фундаментальною потребою розвитку особистості (Коновальчук В., 2017). 
Довіра - це здатність і готовність прощати, виправдовувати, жаліти, не допускати зневаги, терпіти і приймати один одного, відкриватися іншому, а ще не лукавити, чинити пристойно стосовно іншого. Серед особистих якостей довіра - це доброзичливість, такт (також і педагогічний), щирість у взаєминах, поступливість, повага до дитини. («Ми сильні, повинні, повинні нести слабкості безсилих, а не собі догоджати» - Послання Св. Апостола Павла до римлян, 15:1).

Довіра як поняття моральної свідомості та етики є засобом налагодження доброзичливих стосунків між педагогом та дитиною. Так, однією з особливостей педагогічної системи А. Макаренка є віра в людину, необхідність та можливість розвитку ї̈ добрих задатків. Видатний педагог завжди радив дотримуватися гуманістичного принципу: бачити в кожній дитині особистість, розкривати її індивідуальність, красу, здібності. На його думку, до дитини необхідно підходити з оптимістичною гіпотезою, навіть і деяким ризиком помилитися, педагог наголошував, що «не може бути виховання, якщо не зроблена центральна установка про цінність людини» (Макаренко А., 1988, с. 136).

До головних засобів виховання закономірно залічував категорію довіри В. Сухомлинський. На його думку, вихователь своєю довірою не лише засвідчує «визнання моральних якостей свого вихованця, а й начебто відкриває перед вихованцем перспективу подальшого морального розвитку» (Сухомлинський В., 1977, с. 327). Педагог, довіряючи дитині, виявляє передусім «оцінку доброго начала в людині» (Сухомлинський В., 1977, с. 328).

Енергетизм довіри спрямований на формування в дитини самоповаги, самопізнання («звертає погляд дитина на себе, оцінює добро і зло в собі»), творення наставником виховної справи на дитячому довір'ї («дорожіть довір'ям, а отже - беззахисністю дитини»; «владу свою над дитиною будуєте на цьому довір'ї, цій беззахисності» (Сухомлинський В., 1976, с. 639). Ідеї В. Сухомлинського про пріоритетність значення ролі довіри у формуванні гармонійної особистості майбутнього громадянина стали підставою основ педагогіки довіри у 60-х pp. XX ст.

Довіра як форма віри характеризує суб'єкт-об'єктні стосунки, стосунки безумовної готовності й відкритості до обміну в процесі взаємодії. Латинське «credo» у значенні «віра», «мати довіру» вважають праіндоєвропейським за походженням зі значенням «серце даю», воно виявляє особливість змісту довіри як цілісної, центральної категорії, у якій закладена потенційна готовність віддавати, спрямована на зовнішній світ. Відтак праця В. Сухомлинського «Серце віддаю дітям» (1969) є підтвердженням висловленої вище тези про педагогіку довіри.

Довіра й недовіра є фундаментальними почуттями, що визначають подальший розвиток усіх інших видів ставлення особистості до світу, до себе й інших людей. Це почуття виникає дуже рано й залежить від якості отримуваної дитиною материнської турботи. Зауважмо, що почуття довіри не залежить від кількості їжі або проявів батьківської ніжності; швидше воно пов'язане зі здатністю матері передавати своїй дитині почуття впізнаваності, сталості та тотожності переживань. Важливою є рівновага між потребою дитини отримувати і потребою матері давати.

На думку Е. Еріксона, емоційний контакт між матір'ю та дитиною є базисною психологічною моделлю, необхідною для розвитку особистості дитини (Еріксон Е., 2000, с.113). На жаль, така рівновага не може бути досягнута, коли дитина залишається сиротою.

Довіра виступає однією з основних детермінант самоповаги, що є основною умовою саморозвитку особистості. Без довіри й позитивного ставлення до власного Я неможливий успішний розвиток особистості, це потребує передовсім відповідного ставлення інших. Людина не буде вірити в себе, якщо ніхто не повірить у неї. Це позитивне ставлення (довіру) К.Роджерс трактує як тепло, симпатію, емпатію, прихильність, акцептацію, ставлячи за приклад позицію батьків, які нагороджують ніжними почуттями свою дитину, незалежно від її поведінки, дають їй «безумовну любов», любов аgаре. Тільки батьки дають дитині «безумовну» любов, тобто люблять її за те, що вона є (Роджерс К., 1994, с. 165-166).

Особливо гостро сьогодні стоїть проблема формування базової довіри у дітей-сиріт, які виховуються у державник закладах опіки. Зазвичай у таких дітей не сформована «довіра до себе», яка допомагає не вступати з собою в конфлікти чи суперечності. «Довіра до себе» $€$ гарантом, з одного боку, стресостійкості, цілісності а, з іншого, умовою розвитку особистості.

Дослідження М. Бевз, Я. Гошовського, А. Прихожан, Н. Толстих, присвячені психологічним особливостям виховання дітей-сиріт у державних закладах опіки, констатують спрощене емоційне тло спілкування в установах закритого типу. Емоційність педагогів зазвичай знижена, що впливає на тло дитячої активності, виявляється в малій кількості їх звернень до дітей (у 4-10 разів менше, аніж у їх однолітків, котрі виховуються в сім'ї); у контактах зменшена кількість особистісних, інтимних звернень, а ті, що є, емоційно бідні й одноманітні за змістом, здебільшого спрямовані на регламентацію поведінки.

Часта змінюваність вихователів, дефіцит ласки, уваги, емоційного тепла з боку дорослих, переведення вихованців з однієї групи в іншу, з одного дитячого закладу до іншого закріплюють один з найнебезпечніших феноменів сирітства - «втрату базової довіри до світу», яка проявляється в агресивності, підозрілості, нездатності до автономного життя, що має негативний вплив на емоційний і особистісний розвиток дитини (Бевз Г., 2006). Відсутність довірливих стосунків у вихованців державних закладів опіки є причиною емоційної нестійкості, тривожності, фрустрованості, порушення емоційних контактів з тими, хто оточує. Саме встановлення довірливих стосунків вихователя та дитини-сироти є запорукою емоційного комфорту, особистісного розвитку дитини.

Діти заслуговують поваги, довіри та дружніх взаємин, підкреслював Я. Корчак та застерігав педагогів від «нещирої, дешевої довіри» до дітей, «напоказ - друзі, на словах - союзники, на ділі - вороги». Такі педагоги викликають відразу, і як відповідь, - неприязнь дітей, конспірацію» (Корчак Я., 1990, с.12). Вимоги педагога мають поєднуватися з глибокою довірою і повагою до дитини, інакше вимога постає як брутальний тиск, принука. Вияв недовіри до дитини є певною мірою здійсненням насильства стосовно неї. 
Відсутність у вихователя довіри до дитини робить фактично неможливим повноцінний діалог з нею, який є ключовою ланкою успішної педагогічної діяльності та припускає повне взаєморозуміння, позитивне емоційне тло суб'єкт-суб'єктної взаємодії, потребу і можливість саморозвитку. Усе це стає можливим, якщо вихователь виявлятиме в дитині якості, що дають можливість оцінювати її як активного, рівноправного партнера по спілкуванню і взаємодії.

Дослідник В. Сафонов найголовнішою функцією довіри вважає обмін значущими думками і почуттями на основі віри та довіри до партнера. Як ключові функції довіри вчений виокремлює такі: 1) функцію психологічного розвантаження; 2) функцію зворотного зв'язку в процесі самопізнання; 3) функцію психологічного зближення і поглиблення взаємин (Сафонов В., 1981, с. 256-258). На нашу думку, ці функції найкраще підкреслюють бажану суб'єкт-суб'єктну взаємодію дитини-сироти та педагога в умовах державного закладу опіки.

Установлення довірливих стосунків вихователя та дитини-сироти передбачає невтручання в її особистісний простір, довіру до ухвалення самостійних рішень. Суб'єкт-суб'єктна взаємодія вихователя та дитини-сироти це «спільний» простір, перетин життєвого простору дитини та вихователя. Звичайно, що в дитини та й у вихователя залишаються «секретні» проблеми. У дітей є багато причин не довіряти вихователеві, серед яких страх засудження, покарання. Зауважмо, що усвідомлення свого права на помилку, визнання такого права за іншими не применшує, а сприяє росту довіри і водночас відповідальності за власну поведінку, вчинки.

Доцільним, на нашу думку, є використання педагогом техніки

досягнення довіри у стосунках дорослого та дитини В. Рахматшаєвої, яка пропонує п'ять «мовчазних ключів» до довіри:

1) перевірити, чи довіряє вам дитина (техніки невербального спілкування);

2) синхронізування тону і темпу власного голосу з голосом дитини;

3) налаштування на дихання дитини («техніка дзеркала»);

4) використання відповідного ритму рухів («перехресне дзеркало»);

5) намагання надати власному тілу позу, адекватну дитячій («техніка простого наслідування»), (Рахматшаєва В., 1995, с. 26-28).

Відтак досягнення довірливих стосунків - засіб синхронізації досвідів, цінностей і звичок дитини й вихователя. Створювати, виховувати довіру дітей-сиріт до вихователя можна як за допомогою слів, так і засобами невербального спілкування: очима, посмішкою, дотиком, тобто всім, за допомогою чого можна продемонструвати дітям, що вони мають право відкрито виражати свої думки і почуття. При цьому вихователь повинен усвідомити право кожної людини на приховування своїх думок та почуттів, ізольованість і недоторканість внутрішнього світу, і головне, визнати це право за дитиною.

За умови довіри до дітей-сиріт (їхніх слів, намірів, дій, учинків, цінностей) вихователі здатні допомогти вихованцям повірити в себе, знайти взаєморозуміння з навколишньою дійсністю та навчити правильно розуміти світоглядну позицію «іншого», що є незамінним критерієм побудови гармонійних стосунків та успішної суб'єктсуб'єктній взаємодії.

\section{ВИСНОВКИ ТА ПЕРСПЕКТИВИ ПОДАЛЬШИХ ДОСЛІДЖЕНЬ}

Здійснивши аналіз наукових напрацювань дослідників з означеного питання, можемо констатувати, що довіра в суб'єкт-суб'єктній взаємодії вихователя та дитини-сироти стимулює процес відвертості, прозорості, саморозкриття, що виступає умовою результативності продуктивного розвитку особистості дитини-сироти. Вимоги вихователя мають поєднуватися з глибокою довірою і повагою до дитини. Професійна компетентність педагогів, використання вихователем технік досягнення довіри у стосунках з дитиною уможливить частково знизити негативний вплив деприваційних умов державного закладу опіки. Тільки системна реалізація умов, дотримання яких забезпечить реалізацію принципу довіри у вихованні особистості дитини-сироти, допоможе здійснити ефективну підтримку дітям, що залишились без піклування батькі, та підвищити успішність виховного процесу загалом.

Перспективу наших подальших розвідок вбачаємо в обґрунтуванні теоретико-методологічних основ технологій виховання дітей-сиріт на основі реалізації етично-альтруїстичного принципу.

\section{СПИСОК ВИКОРИСТАНИХ ДЖЕРЕЛ}

Бевз, Г. М. (2006). Прийомні сім'ї (оцінка створення, функціонування та розвитку) К.: Главник.

Бойко, А. М. (2012). Феномен «суб'єкт-суб'єктні відносини» - стратегія подальшого розвитку педагогічної теорії і практики. Гуманізація навально-виховного процесу : зб. наук. праць, 8 (1), Слов'янськ : СДПУ.

Эриксон, Э. Г. (2000). Детство и общество. СПб. : Речь.

Коновальчук, В. І. (2017). Розвиток творчого потенціалу особистості у просторі освіти. Дис....доктора філософських наук за спеціальністю 09.00.10 - філософія освіти. Київ.

Корчак, Я. (1990). Как любить ребёнка: книга о воспитании; пер. с польск. / Я.Корчак. М.: Политиздат.

Макаренко, А.С. (1988). Книга для родителей. Москва. Просвещение.

Пеша, І.В. (2000). Соціальне становлення дітей в дитячих будинках сімейного типу автореф. дис. 13.00 .05 - соціальна педагогіка. Київ.

Рахматшаева, В.М. (1995). Граматика общения. Москва.

Роджерс, К. (1994). Взгляд на психотерапию: Становление человека : пер. с англ. Москва: Прогресс.

Сафонов, В.С. (1981). О психологии доверительного общения. Проблема общения в психологии / под ред. Б.Ф. Ломова. Москва : Наука, 256-258. 
Султанова, Н.В. (2018). Теорія і практика соціального виховання дітей в інтернат них закладах освіти України (1956-початок XXI ст.). 13.00.01 - загальна педагогіка та історія педагогіки. Дис.... доктора наук. Тернопіль.

Сухомлинський, В.О. (1977). Слово вчителя в моральному вихованні. Вибр. тв..: в 5 т. К.: Рад. шк.Т.5.

Сухомлинський, В.О. (1976). Сто порад учителеві. Вибр. тв..: в 5 т. К.: Рад. шк. Т.2.

\section{REFERENCES}

Bevz, H.M. (2006). Pryiomni simi (otsinka stvorennia, funktsionuvannia ta rozvytku) Kyiv: Hlavnyk.

Boiko, A. M. (2012). Fenomen «subiekt-subiektni vidnosyny» - stratehiia podalshoho rozvytku pedahohichnoi teorii i praktyky. Humanizatsiia navalno-vykhovnoho protsesu : zb. nauk. prats, 8 (1), Sloviansk : SDPU.

Konovalchuk, V. I. (2017). Rozvytok tvorchoho potentsialu osobystosti u prostori osvity. Dys....doktora filosofskykh nauk za spetsialnistiu $09.00 .10-$ filosofiia osvity. Kyiv.

Korchak ,YA. (1990). Kak lyubit rebënka: kniga o vospitanii; per. s polsk. Moscow: Politizdat.

Makarenko, A.S. (1988). Kniga dlya roditeley. Moscow: Prosveschenie.

Pesha, I.V. (2000). Sotsialne stanovlennia ditei v dytiachykh budynkakh simeinoho typu Avtoref. dys. 13.00 .05 - sotsialna pedahohika. Kyiv.

Rahmatshaeva, V.M. (1995). Gramatika obscheniya. Iz-vo «Semya i shkola», M.

Rodjers, K. (1994). Vzglyad na psihoterapiyu: Stanovlenie cheloveka : per. s angl. Moscow: Progress.

Safonov, B.C. (1981). O psihologii doveritelnogo obscheniya. Problema obscheniya v psihologii / pod red. B.F. Lomova. Moscow: Nauka, $256-258$.

Sultanova, N.V. (2018). Teoriia i praktyka sotsialnoho vykhovannia ditei v internat nykh zakladakh osvity Ukrainy (1956-pochatok KhKhl st.). 13.00.01 - zahalna pedahohika ta istoriia pedahohiky. Dys.... doktora nauk. Ternopil.

Sukhomlynskyi, V.O. (1977). Slovo vchytelia v moralnomu vykhovanni. Vybr. tv..: v 5 t. K.: Rad. Shk.T.5.

Sukhomlynskyi, V.O. (1976). Sto porad uchytelevi. Vybr. tv..: v 5 t. K.: Rad. Shk. T.2.

Статтю подано до редколегії 01.06 .2020 p.

Рекомендовано до друку $\quad 12.06 .2020$ p. 